\title{
ОСОБЛИВОСТІ ФУНКЦІОНУВАННЯ КОНФІКСАЛЬНИХ ІМЕННИКІВ У ТВОРАХ О. ДОВЖЕНКА
}

\begin{abstract}
Качайло К. А. Особливості функціонування конфіксальних іменників у творах О. Довженка.

У статті розглянуто особливості функціонування в художньому тексті, специфіку семантики та словотвірної структури конфіксальних іменників, використаних у кіноповістях О. Довженка; проаналізовано деривати, утворені шляхом приєднання до мотивуючої основи конфіксів із постпозитивними компонентами -/ü/a, $-о \kappa,-н и \kappa,-u и(я), \varnothing$ (матеріально не виражена друга частина) та різноманітними препозитивними частинами.
\end{abstract}

Ключові слова: конфікс, постпозитивний компонент, конфіксальний дериват.

Качайло К. А. Особенности функционирования конфиксальных имен существительных в произведениях А. Довженко.

В статье рассматриваются особенности функционирования в художественном тексте, специфика семантики и словообразовательной структуры конфиксальных имен существительных, использованных в произведениях А. Довженко; анализируются дериваты, образованные путем присоединения к мотивирующей основе конфиксов с постпозитивными компонентами -/ŭ/a, -ок, -ник, -иц(я), ø (материально не выраженная вторая часть) и разнообразными препозитивными частями.

Ключевые слова: конфикс, постпозитивный компонент, конфиксальный дериват.

Kachajlo K. A. Peculiarities of functioning confixal nouns in O. Dovzhenko's literary works.

The article gives a broad outline of confixal nouns in a fictional text, their semantic, world building and functional peculiarities basing on Dovzhenko's cinematic stories. It also analyses derivations built by joining such confixes with postpositive components as $-/ \tilde{u} / a$, 
$-о \kappa,-н u \kappa,-u u(\Omega), \varnothing$ (the second part is not materially expressed) as well as various prepositive elements to the motivational basis.

Key words: confix, postpositive component, confixal derivative.

Конфіксацію як словотвірне явище, а також окремі види формантів у слов'янському мовознавстві описали А. А. Амінова, Л. В. Владимирова, Е. В. Казанська, В. М. Марков, Г. О. Ніколаєв, М. К. Пишкало, В. П. Старинін, С. Х. Чекменьова, П. П. Шуба. В українській мові систему конфіксального словотворення іменників вивчали І. О. Іншакова, Л. М. Стовбур, С. В. Воропай та інші. Доречно згадати, що конфікс - це одна, двоелементна, переривчата морфема, яка виражає одне словотвірне значення і обрамляє твірну основу 3 обох боків. Початковий (препозитивний) та кінцевий (постпозитивний) компоненти цієї морфеми лише формально можуть збігатися $з$ префіксом і суфіксом, оскільки значення префікса й суфікса не можуть складатись у єдине словотвірне значення. «Особливістю дериваційної семантики конфіксальних формантів $\epsilon$ те, що їхня постпозитивна частина передає загальне відношення предмета до поняття, позначуваного мотивуючим словом (виконує класифікаційну функцію показника найменування предмета, особи чи абстрактного поняття), а препозитивна - конкретизує це загальне відношення, виражаючи різні значеннєві модифікації (лексичне співзначення)» [1, с. 16].

Словотворення мовних одиниць лінгвісти розглядають не тільки за словниковим матеріалом та мовою пам'яток, а й за текстами творів художньої літератури, оскільки використання письменниками тих чи інших дериватів свідчить про індивідуально-авторські риси митців, їх чуття слова та специфіку художньої мови.

Мета статті - з'ясувати особливості функціонування конфіксальних іменників у художньому тексті та їх семантику i словотвірну структуру. Джерельною базою для дослідження стали кіноповісті Олександра Довженка.

Фактологічний матеріал засвідчує шістдесят два конфіксальних іменникових похідних слова, використаних митцем. Вивчення словотвірної структури означених дериватів дає змогу стверджувати, що в їх творенні взяли участь конфіксальні морфеми 3 постпозитивними частинами -/ŭ/a, -ок, -ник, -иц(я), ø (матеріально не виражена друга частина) та різноманітними препозитивними частинами. 
За нашими даними, більшу частину всієї кількості дібраних конфіксальних дериватів складають ті, що утворені шляхом приєднання конфікса 3 постпозитивною частиною -/ü/a, зокрема додаванням до твірної основи таких формантів: об-...-/ü/a, nid-...-/ü/a, без-...-/ü/a, за-...-/ü/a, по-...-/ü/a, межи-...-/ü/a, над-...-/ü/a, недо-...-/ü/a, роз-...-/ü/a, перед-...-/u/a, пере-...-ü/a, су-.../ü/a, yз-...-/u/a. Серед визначених тринадцяти афіксів найбільшою активністю при творенні іменників характеризується конфікс без-...-/u/a, який виокремлюється у словотвірній структурі дериватів із загальним значенням словотвірного типу «те, у якому немає чогось, що позначено твірною іменниковою основою», наприклад: а) найменування місцевості: безмежжя - В холодне безмежжя неслись свист, $і$ виття, $і$ вищзання радіошифрів [2, с. 250]; безлюддя - Холод осів на околиці, на безлюдді, nід старим хлівом [2, с. 449]; б) назви психічних, фізичних та емоційних станів особи: безстрашщя - Слава крові вашій $i$ безстрашшю! [2, с. 258]; безсоння - 3 туману почали виринати озброєні мокрі люди, з запаленими від безсоння очима [2, с. 86]; безсмертя [1, с. 124] - Раз у тисячу років куля не повинна брати людину. Це безсмертя [2, с. 129]; Тут боролось безсмертя зі смертю [2, с. 235]; в) найменування моральних переконань та статусу людей: безбожжя та безвір'я - Блудодійні й богоогидні схрещування древес $i$ злаків божих сіють у народі плевели безвір'я й безбожюя! [2, с. 375]; безправ'я - Чи творив він грізну історію свого народу і нещасної, загубленої в морі безправ'я й страшних випадковостей молодої своєї сім '̈? [2, с. 231]; г) назви ознак навколишнього середовища: безладдя - Тікали в безладді кінні і піші [2, с. 389]; безгоміння - I від глухого тупоту його ніг $i$ жагучого шепоту серед сонного безгоміння утворилася така тиша [2, с. 76].

Конфіксальні іменники 3 морфемою по-...-/u/a $\epsilon$ прикладами реалізації кількох напрямків загального словотвірного значення: a) «те, що у просторі займає певне положення відносно чогось, що називає твірна основа», наприклад, найменування місцин: подвір я На подвір'ях і кошарах ремитали лежма воли [2, с. 73]; бігли врозтіч мальовничі вулички й стежки до розкиданих у зелені подвір'їв та хат [2, с. 338]; покуття - Оставшись один, Запорожець зняв з покуття nортрет Сталіна [2, с. 169]; б) «те, що у часовому відношенні відбувається після того, що позначає твірна основа», наприклад, назви відповідних об'єднань людей: покоління - Мати-Земле! Зникнемо ми, 
зміняючись на твоєму лоні, покоління за поколінням, як хвилі в океані [2, с. 340]; подружжя - Іван і Уляна вирішили стати подружжям [2, с. 289]; найменування сукупності тварин: поголів'я - Архипові Білоконю, який підриває колгоспний лад, приховує насіння, нищчтть поголів'я худоби [2, с. 62]; назва стану людини: похмілля - 3 веселим похміллям вас [2, с. 386]; в) «подібний до того, що називає твірна основа», наприклад, найменування стану середовища: повітря [1, с. 131] - Все повітря прийшло в шалений рух [2, с. 236]; Воно ніби як повітрям перелетіло на мене [2, с. 252].

Цікавими за семантикою прикладами представлений словотвірний тип із конфіксом за-..-/ü/a, загальне словотвірне значення якого полягає в називанні предметів, явищ, місць, що знаходяться позаду чогось або когось, названого твірною основою. У проаналізованих творах Олександра Довженка це в основному географічні назви, наприклад: Запоріжжя - Так і не почувши, звідки він родом, - $з$ Запоріжжжя, Рязані чи з далекого Сибіру, - сестра поволі виймає листа з конверта [2, с. 50]; Заріччя - на Заріччі шо не хата - повнісінько окупантів [2, с. 272]; Задніпров'я - Орлюк оглянув своїх гостей, руїни навколо й величну далечінь Задніпров'я [2, с. 303]; Загребелля - Рятуй людей на Загребеллі. Потопають, чув? [2, с. 451].

Кілька конфіксальних іменників утворені шляхом приєднання до твірної основи форманта nid-...-/u/a, який надає похідному слову значення розташування нижче чогось або під чимось, що називає твірна основа, наприклад, найменування місцин: підпіччя - He підходь! - пролунав відчайдушний крик з підпіччя, після чого знов зацокотів кулемет [2, с. 323]; підніжжя - Вона поклала біля його підніжжя дитину, а сама припала до бронзових грудей $і$ застигла [2, с. 307]; підпілля - представники влади й партійний актив вирушили на схід, залишивши в підпілля окремі лише групи організаторів опору [2, c. 260].

Решта конфіксів із постпозитивною частиною -/й/а утворюють поодинокі іменникові деривати, які можна об'єднати в такі лексикословотвірні групи: а) назви певної місцевості або території, що $є$ точкою перетину чогось, наприклад: перехрестя [1, с. 143] оглядаючись на всіх перехрестях, чи не летить десь до нього казковою птицею рідна його доля, тільки зараз відчув він уповні своє горе [2, с. 176]; місця, що є точкою розгалуження чогось: роздоріжжя - По всіх роздоріжжях чули люди вночі, як стогнала в журбі земля () К. А. Качайло, 2014. 
[2, с. 173]; території, що розташована перед чимось: переддвір'я - Це були мертві переддвір'я Києва [2, с. 286]; місцевості, що розташована між чимось: Межсигір'я - Раптом замигтів, запалахкотів вогнями весь правий берег від Києва до Вишгорода й Межигір'я [2, с. 279]; місця, що знаходиться біля чогось: узголів'я - $B$ узголів'ї покійниці горіли свічки [2, с. 380]; б) найменування частин тіла, що знаходиться зверху того, що називає твірна основа: надпліччя - Від плечового суглоба гангрена поплазувала вже через надпліччя до ииї [2, с. 282]; або розташована навколо того, що названо мотивуючим словом: обличчя - Весь ясний соняиниковий світ стояв нерухомо, наче хор вродливих дітей, щзо втупили у височінь свої радісні обличчя [2, с. 58]; в) астрономічна назва зі значенням сукупності: сузір'я - $B$ середині ХХ століття, коли все уже $\epsilon$, щзоб перетворити всю землю в рай, в сузір'я ї̈ народів, великих $і$ малих, - щз зробили з Європою ваші загиблі батьки, які були отруєні мертвою ідеєю фашизму?! [2, с. 316]; г) абстрактна назва зі значенням «те, що відбувається перед чимось, названим мотивуючим словом»: передвістя - Немов передвістя біди скувало всю нашу землю [2, с. 406]; д) найменування психологічного стану особи: недовір'я - Лиманчук, хоча й підкоривсь наказу, сприйняв це як знак недовір'я $і$ партизанської пихи [2, с. 216].

Важливо зазначити, що слово обличчя використовується письменником у кожному дослідженому творі по кілька разів, наприклад: Трохи заросле молоде обличчя, ясна усмішка [2, с. 36]; Суворі ц̌ задумливі обличчя в товаришів [2, с. 51]; На прощання Василь пригорнув Наталчину голову до свого серия, $і$ обличчя його набрало на диво серйозного, глибокого виразу [2, с. 74]; Загорілі молоді обличчя припорошені золотим пилом степових шляхів [2, с. 132]; Високі небуденні думи світились на їх простих обличчях [2, с. 238]. Цікаво, що О. Довженко надає перевагу згаданому деривату, описуючи позитивних героїв, та використовує різні епітети: $я \kappa \mathrm{nim}$ котився по запорошених обличчях $i$ спинах $і$ як вилискували зуби на веселих засмаглих обличчях [2, с. 69]; Засмалені сонцем, закурені, мокрі од поту обличчя вилискували радістю $i$ здоров'ям [2, с. 159]. Рідко автор згадує цю частину тіла, характеризуючи негативного героя, наприклад: розлютився Чуприна чи Кравчина, через щзо кількість веснянок на його обличчі зразу потройлась [2, с. 70].

За даними фактологічного матеріалу, на другому місці за кількістю стоять конфіксальні іменники, утворені шляхом приєднання до твірної 
іменникової основи конфіксів із другим компонентом -ок, зокрема таких: за-..-ок, па-..-ок, полу-..-ок, при-...-ок, під-..-ок, про-...-ок. Словотвірний тип із конфіксом за-...-ок, загальне словотвірне значення якого полягає в називанні того, що знаходяться позаду чогось або когось, названого твірною основою, представлений найширше. Наприклад, у текстах кіноповістей Олександра Довженка зафіксовані найменування місць, що знаходяться позаду або на задній стороні того, що названо мотивуючим словом: запічок - А кому не вистачало місия за столом, ті сиділи на лавах, на скрині, на полу і навіть у запічку [2, с. 102]; Генерал витяг з запічка пучечок сухих чорнобривців, понюхав і ледве не заплакав [2, с. 306]; Я одкриваю очі $і$ не встигаю щзе як слід прочуматись, аж мати підходить до запічка [2, с. 446]; Я хутко злізаю на запічок, звідти плигаю в дідові валянизі [2, с. 447]; засторонок - Заліз я хутко в старий човен, щзо стояв у клуні в засторонку, і почав думати [2, с. 440]; застінок - У застінку били й катували людей [2, с. 179]; завулок - довгий курний слід клуботів за ним над тихими завулками [2, с. 76]; Ось вона загнала їх у завулок і схопила [2, с. 193]; або заулок - Билися в заулках врукопашну, вручну [2, с. 126]; затишок - Нема щзастя! Нема затишку! Втрачено спокій в Свропі [2, с. 39].

Два деривати, за нашими даними, утворені шляхом приєднання конфікса про-...-ок. Ці іменники $є$ прикладами реалізації словотвірного значення «те, що знаходиться або розташовується між тим, що називає твірна основа», наприклад: просторові найменування провулок - В темному провулку перешіптувалась група повстанців [2, с. 89]; Вздовж города провулком біг переляканий всмерть його товариш Гаркавенко Іван [2, с. 160]; Олеся й Христя бігали у тісних містечкових провулках біля станиї [2, с. 193]; Пройшла один провулок, другий [2, с. 375]; просвіток-Важкі хмари облягали небо, й не було майжсе просвітку [2, с. 260].

Решта конфіксів виокремлюється у словотвірній структурі поодиноких прикладів. Морфема під-...-ок наявна в найменуванні особи, яка ще не досягла повного виявлення ознак, названих мотивуючим словом, наприклад: підліток - На зріст куркуляка був такий високий, що Василь перед ним здавався підлітком [2, с. 72]; Ідуть! Німці ідуть! - гукнув одчайдушно у вікно переляканий підліток $i$ зник [2, с. 84]; Молоді юнаки, підлітки, й старі батьки, i навіть дівчата, котрим у століттях не снилось ніколи таке життя, творили в загонах сувору помсту народу [2, с. 224].

(ㄷ.К. А. Качайло, 2014. 
Конфікс па-...-ок надає похідному слову значення неповноти вияву того, що називає твірна основа. У кіноповістях письменника це найменування місцевості, наприклад: пагорок - На мальовничому пагорку край села <...> в неділю по обіді зійшлась сила народу [2, с. 68]; На вишгородському пагорку ивіли вишні [2, с. 339]; Загасли жертовники на пагорку, іржаві танки зяяли чорно-рудими пробоїнами [2, с. 340].

Словотвірне значення «розташування поблизу того, що називає твірна основа» реалізується в іменнику 3 конфіксом $n p u-\ldots-о к-$ найменуванні місця: припічок - Сядеш у кариію, - сказав Макар $i$ понюхав на припічку смажене порося [2, с. 451]. Наявний один дериват 3 морфемою полу-..-ок, який $\epsilon$ назвою предмета, що наполовину менший від названого твірною основою: полумисок - Вid хатини підходили до нього син Опанас $і$ онуки, Василь $і$ Орися, $з$ полумиском грушок [2, с. 58].

Далі за кількістю йдуть деривати, утворені шляхом приєднання до твірної основи конфіксів 3 постпозитивною частиною -ник, зокрема таких: су-...-ник, під-...-ник, на-..-ник, спів-...-ник, по-...-ник, без-..-ник. Як показав фактологічний матеріал, такі конфіксальні іменники $\epsilon$ переважно назвами осіб або істот зі значенням «той, хто є спільником у чомусь», наприклад: сучасник - я, народжена для добра людина, мушу якось освідчитись моїм сучасникам, друзям $і$ ворогам усього світу [2, с. 249]; холодна бистрина понесла його вниз за течією разом 3 тисячами його сучасників [2, с. 281]; Так, містер Майєрс сказав, щзо ие геніально і щзо він щасливий бути вашим сучасником взагалі [2, с. 350]; напарник - Ревуть бики од пахощів кривавих і риють землю рогом коло забитих напарників своїх рогатих [2, с. 153]; Пораненого Гаркавенка відразу ж замінив його напарник Грачов [2, с. 254]; співбесідник-Саме в цей час до співбесідників швидко підійшов чиновник особливих доручень [2, с. 351]. Значення «той, хто не має чогось, названого мотивуючим словом» простежується в конфіксальному іменнику безвірник - I тут ти проти бога, нечестивець, безвірнику лукавий! [2, с. 453].

У кіноповістях Олександра Довженка наявні 3 означеними конфіксами й назви певних явищ або предметів, наприклад: супутник - Довго говорили вони про страшне, і обом їм такий приємний був цей нічний пухнастий супутник юності [2, с. 74]; Однак по мірі наближення німців у многих забігали по спині мурашки, та тут їх зразу ж виручив природний супутник їхнього життя - сміх [2, с. 240]; посередник - знайшов спосіб створення нових рослин на 
основі віддаленої гібридизачії, шляхом використання посередника [2, с. 396]; підсвічник - $i$ знову підсвічники й ложки - все це носилось гарячим маревом перед очима лютих куренів [2, с. 124].

Деривати, утворені шляхом приєднання до твірної основи конфіксів із матеріально не вираженим другим компонентом (без-..., не-..ø, $п р и-\ldots \varnothing)$, налічують п’ять мовних одиниць. Так, наприклад, конфікс без-... виокремлюється в похідних словах, які називають «те, у якому немає чогось, що позначено твірною іменниковою основою». За нашими даними, це найменування місцевості: безодня - Постояв осиротілий батько в полі, і хоч не було навколо ні безодень, ні гір, здавалось, голова його сягала неба [2, с. 77]; Стою опівночі над безоднею скорботи, аби не взяв його ні меч, ні вогонь, ні вода [2, с. 250]; Куди покотився $б$ світ? B яку безодню? [2, с. 257]; а також найменування особи: бездара - А чи вони такі вже бездари? [2, с. 406].

Конфіксальні іменники 3 афіксом не-..ø містять значення заперечення чогось, названого іменниковою основою. В опрацьованих художніх текстах зафіксовано назву істоти: немовля - Ось підвелась мати, пригортаючи до грудей немовля [2, с. 39]; сказав один немолодий уже поранений, тримаючи на грудях забинтовану руку, як немовля в білосніжних пелюшках [2, с. 267]; та найменування дня тижня: неділя - була ще неділя $і$ якесь свято [2, с. 57]; в неділю сюди сходились на посиденьки й сиділи в піску баби [2, с. 62]. Морфема $n p u-\ldots \varnothing$ виокремлюється у словотвірній структурі іменника, що позначає неповноту вияву дії: присмерк «напівтемрява після заходу сонця» [1, с. 189] - Дівчат любив лише в присмерку [2, с. 75].

За нашими даними, зафіксовано лише два іменники, утворені шляхом приєднання до твірної основи конфіксів 3 другою частиною -иц(я). Зокрема, шляхом приєднання форманта по-...-иц(я) виникло слово, яке є назвою задньої частини голови над шиєю: потилиця Вбитий у потилицю офіцерською кулею, він тихо падає [2, с. 35]; Якщу я зажадаю пострілу не в потилицю, а в око? [2, с. 53]; На потилицю насідайте! [2, с. 244]. Морфема о-...-иц(я) виокремлюється у словотвірній структурі найменування місцевості, яка прилягає до основного місця проживання людей: околиця - Живе швець десь на протилежній околиці міста [2, с. 49]; Каламутними потоками вступали окупанти на площі, розтікалися по околицях [2, с. 86].

Отже, використані в кіноповістях Олександра Довженка конфіксальні іменники мають цікаву семантику й особливу 
словотвірну структуру, що дає змогу зробити висновок про певну важливість їх функціонування в художньому творі.

\section{Література}

1. Білоусенко П. І. Нариси 3 історії українського словотворення (іменникові конфікси) / П. І. Білоусенко, І. О. Іншакова, К. А. Качайло, О. В. Меркулова, Л. М. Стовбур. - Запоріжжя - Кривий Ріг : ТОВ «ЛІПС» ЛТД, 2010. - 480 с.

2. Довженко О. Кіноповісті. Оповідання / Олександр Довженко. - К. : Наукова думка, 1986. $-710 \mathrm{c}$.

Стаття надійшла до редакиії 24.10.2014 p. 